\title{
COMPARATIVE ANALYSIS OF DIFFERENT MEAT TRACEABILITY SYSTEMS USING MULTIPLE CRITERIA AND A SOCIAL NETWORK APPROACH
}

\author{
Doi:http://dx.doi.org/10.1590/1809-4430-Eng.Agric.v35n2p340-349/2015
}

\section{IRENILZA DE A. NÄÄS ${ }^{1}$, MARIO MOLLO NETO ${ }^{2}$, ODUVALDO VENDRAMETTO ${ }^{3}$, SIMONE A. CANUTO ${ }^{4}$}

\begin{abstract}
The adoption of a proper traceability system is being incorporated into meat production practices as a method of gaining consumer confidence. The various partners operating in the chain of meat production can be considered a social network, and they have the common goal of generating a communication process that can ensure each characteristic of the product, including safety. This study aimed to select the most appropriate meat traceability system "from farm to fork" that could be applied to Brazilian beef and pork production for international trade. The research was done in three steps. The first used the analytical hierarchy process (AHP) for selecting the best onfarm livestock traceability. In the second step, the actors in the meat production chain were identified to build a framework and defined each role in the network. In the third step, the selection of the traceability system was done. Results indicated that with an electronic traceability system, it is possible to acquire better connections between the links in the chain and to provide the means for managing uncertainties by creating structures that facilitate information flow more efficiently.
\end{abstract}

KEYWORDS: analytic hierarchy process, food traceability, social network analysis-SNA.

\section{ANÁLISE COMPARATIVA DE DIFER ENTES SISTEMAS DE RASTREABILIDADE DE CARNE UTILIZANDO ABORDAGEM DE MÚLTIPLOS CRITÉRIOS E DE REDES SOCIAIS}

RESUMO: A adoção de um sistema de rastreabilidade apropriado tem sido incorporada às práticas de produção de carne, como forma de ganhar a confiança do consumidor. Os vários parceiros operando na cadeia de produção de carne podem ser considerados como uma rede social, e eles têm o objetivo comum de gerar um processo de comunicação que assegura cada característica do produto, incluindo segurança. Este estudo objetivou selecionar o sistema mais apropriado de rastreabilidade de carne "da fazenda à mesa", que pudesse ser aplicado à produção brasileira de carne bovina e de suína, para o mercado internacional. A pesquisa foi feita em três passos. No primeiro, foi utilizado o processo de análise hierárquica (AHP) para selecionar a melhor forma de rastreabilidade do rebanho dentro da fazenda. No segundo passo, os atores da cadeia produtora de carne foram identificados, para se construir a estrutura e definir-se cada função dentro da rede. No terceiro passo, a seleção do sistema de rastreabilidade foi efetivada. Os resultados indicaram que, com o sistema eletrônico de rastreabilidade, é possível conseguir-se melhores conexões entre os elos da cadeia e prover meios de gerenciar incertezas através da criação de estruturas que facilitem o fluxo da informação mais eficientemente.

PALAVRAS-CHAVE: processo analítico hierárquico, rastreabilidade de alimentos, análise de redes sociais-SNA.

\footnotetext{
${ }^{1}$ Eng $^{\mathrm{a}}$ Civil, Prof. Doutora, Programa de Pós Graduação em Enga de Produção-UNIP, São Paulo - SP, Fone: (11) 5586- 4000, irenilza@gmail.com

${ }^{2}$ Eng $^{\circ}$ Industrial, Prof. Doutor, Eng ${ }^{\mathrm{a}}$ de Biossistemas- UNESP/Tupã - SP, mariomollo@tupa.unesp.br

${ }^{3}$ Físico, Prof. Doutor, Programa de Pós Graduação em Enga

${ }^{4}$ Adminstradora, Dra. em Eng de Produção, São Paulo-SP, simcanuto@gmail.com 


\section{INTRODUCTION}

Accurate and complete tracking records for products can reduce the market risk by limiting the scope of a safety threat because potentially affected products can be better defined and contained (ROTH \& DOLUSCHITZ, 2006). A number of collaborative studies have been undertaken in meat production to improve on-farm data acquisition (GOSÁLVEZ et al., 2007) and the communication within the food production chain to enable early warnings and an allencompassing health management system (PETERSEN et al. 2002).

The adoption of a feasible traceability system by livestock producers involves (a) the selection of the right identification scheme for the animals (ID), (b) the ability to follow up with the herd management data (SCHEMBRI et al., 2007), (c) easiness for the workers handling the system (GOSALVEZ et al., 2007), (d) high reliability (SCHEMBRI et al., 2007), and (e) implementation at a low cost (LAMBOOIJ et al., 1999). The traceability system data also needs to interact with the governmental health agencies and provide continuous information for meat production advisory boards, especially those related to international trade (PETERSEN et al., 2002; MUS, 2006).

Amongst the available multi-attribute approaches, the Analytic Hierarchy Process (AHP) has the capability to combine different types of criteria in a multi-level decision structure to obtain a single score for each alternative and to rank all of the alternatives. Several studies are published about distinct scenarios and arrays of AHP, indicating the suitability of this analysis in the selection of criteria (VAIDYA \& KUMAR, 2006).

The concept of traceability "from farm to fork" involves several linked actions between market segments and governmental bodies, which can be considered similar to a social network, and it can be studied using the principles of Social Network Analysis (SNA). SNA has its origins in the studies of patterns of communication, influence and interactions within social groups (RICHARDSON, 2009). Furthermore, a method of drawing on graph theory was developed for capturing and analysing the relationships among members of a group with specific links and interactions (ABEBE et al., 2010).

The objective of this research was to demonstrate the most suitable meat traceability system "from farm to fork" that could be applied to Brazilian pork production with a focus on international trade.

\section{MATERIAL AND METHODS}

The research was carried out using three steps: (1) the selection of a traceability system for on-farm livestock production, (2) the development of a traceability network array from farm to consumer by simulating the product path in the designed network and the interaction of food chain players, and (3) the selection of the most suitable meat traceability system for Brazilian beef and pork production.

\section{Selection of a livestock traceability system using AHP}

The use of AHP involves the following steps: (a) structuring the selection problem, (b) identifying the technological options, (c) identifying the applied criteria, (d) developing the weighting schemes, and (e) ranking management or technological options.

(a) The fundamental goal was to select the proper livestock (beef and pork) traceability system with the purpose of bringing adequate confidence to the international meat trade. Several attributes were adopted at four levels (Figure 1), ranging from items of common sense, such as assurance of basic animal health, feed quality, and good management, to others that require specific understanding, such as health quality, which a consumer is not able to detect prior to purchasing and for which a third party is required to verify compliance with specific standards (VILLALOBOS et al., 2010).

(b) Although several solutions to livestock traceability transformed ahead into meat traceability might theoretically be feasible, they are often represented as disconnected choices due to technical 
and/or other restrictions (PETERSEN et al., 2002; HOBBS, 2004). This research analysed three kinds of livestock identification systems, electronic and manual systems and a hybrid scheme using both manual and electronic systems, for two farm animal species: beef cattle and swine.

(c) Livestock traceability systems can vary from simple trace back arrangements to systems that provide identity preservation and quality assurance. A suitable traceability system needs to grant stakeholders reliability, safety, reasonable cost, good performance and convenience (MUS, 2006). It is also desirable that all aspects of the benefits outweigh the costs (ROTH \& DOLUSCHITZ, 2006). The criteria were chosen based on the current literature (HOBBS, 2004; EUCLIDES FILHO, 2004; SCHEMBRI et al., 2007).

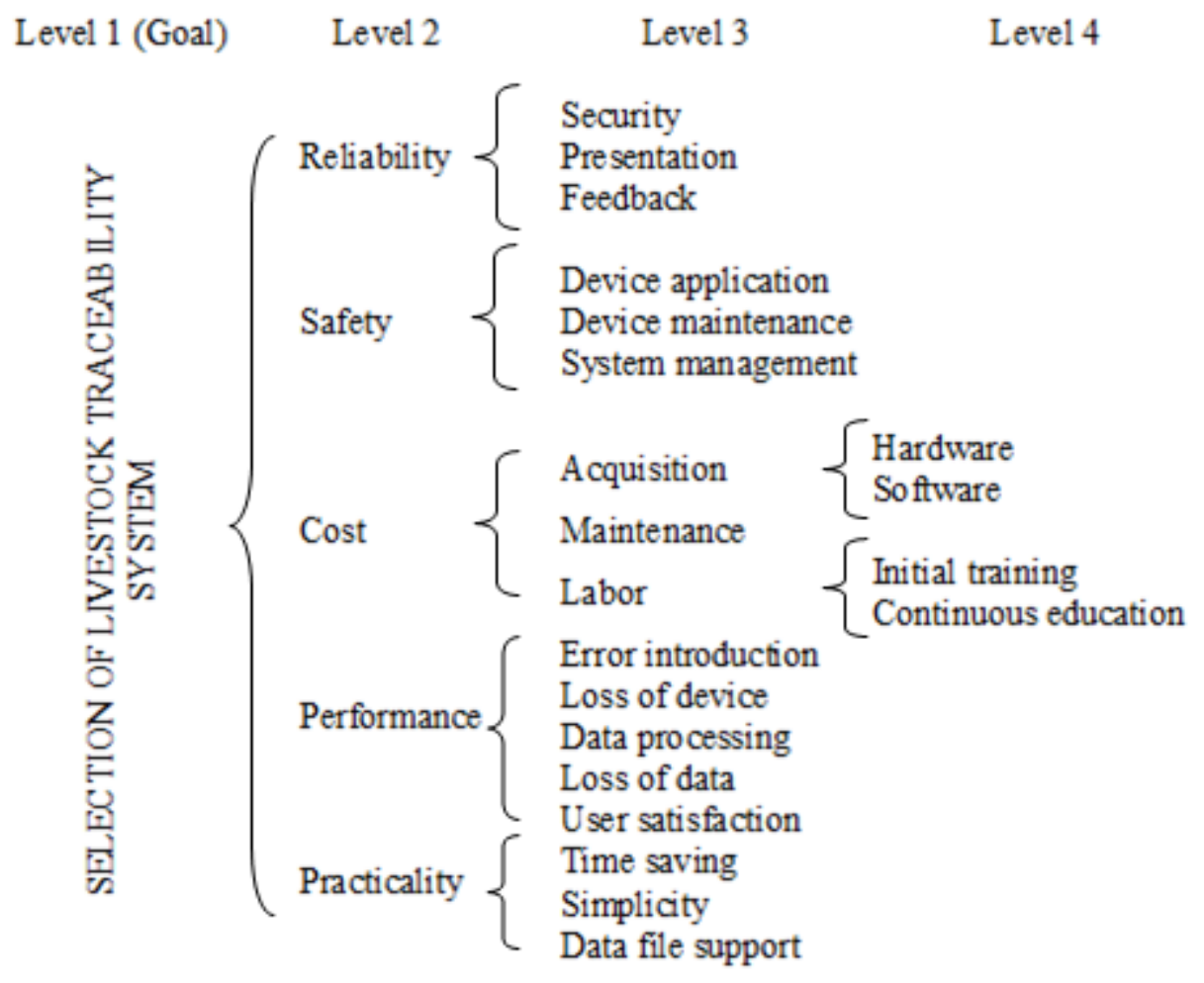

FIGURE 1. Scheme of the criteria chosen for the goal of selecting the most appropriate livestock traceability system.

(d) The purpose of the AHP is to provide a vector of weights expressing the relative importance of the layout alternatives for each criterion. The adopted scale of importance was defined according to SAATY (1980), using a 1 to 9 scale for pairwise comparison.

(e) In the application of the AHP approach, a pairwise comparison matrix is formed. In the pairwise comparison matrix, rows and columns are allocated to the components belonging to the same parent component in the decision hierarchy (Eq. 1). The weight of component $i$ compared to component $j$ concerning the parent component is determined using Saaty's scale and assigned to the $(i, j)^{\text {th }}$ position of the pairwise comparison matrix (SAATY, 1980) that is chosen to support comparisons within a limited range but with sufficient sensitivity. The reciprocal of the assigned number is assigned to the $(j, i)^{\text {th }}$ position automatically. Once the pairwise comparison matrix is formed, weights of components are calculated by solving for the eigenvector of the pairwise comparison matrix. 


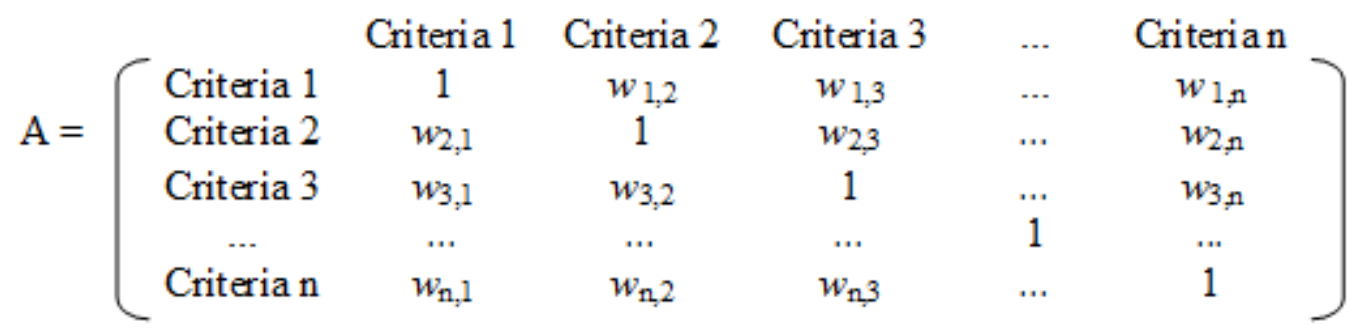

where,

$\mathrm{w}_{i, j}$ is the weight of importance, meaning that the weight of criteria $i$ is more important than $j$. The pairwise comparisons will then be made between each pair of factors at a given level of the hierarchy based on their contribution toward the factor at the level immediately above. These pairwise comparisons yield a reciprocal $(n, n)$-matrix $A$, where $\mathrm{a}_{\mathrm{ii}}=1$ (diagonal elements) and $\mathrm{a}_{\mathrm{ji}}=1 / \mathrm{a}_{\mathrm{ij}}$. Suppose that only the first column of matrix $A$ is provided to state the relative importance of factors $2,3, \ldots, n$ with respect to factor 1 . There is no consistency except for that obtained by setting $\mathrm{a}_{\mathrm{ji}}=1 / \mathrm{a}_{\mathrm{ij}}$. Therefore, the comparison needs to be repeated for each column of the matrix, i.e., independent judgments must be made for each pair. $A$ is consistent if and only if $\lambda_{\max }=n$. However, the inequality $\lambda_{\max }>n$ always exists. Therefore, the average of the remaining eigenvalues can be used as a "consistency index" (CI, Eq 2), which is the difference between $\lambda_{\max }$ and $n$ divided by the normalising factor $(n-1)$.

$$
\mathrm{CI}=\left(\lambda_{\max }-n\right) /(n-1)
$$

The CI of the problem is compared with the average random consistency index (RI) obtained from as sociated random matrices of order $n$ to measure the error due to inconsistency (SAATY, 1980). A consistency ratio $(C R=C I / R I)$ value $\leq 0.1$ should be maintained for the matrix to be consistent; otherwise, the pairwise comparisons should be revised. Computational analysis was done using the software EXPERT CHOICE ${ }^{\circledR}$ (2009).

\section{Development of a traceability network array using the social network concept}

Network analysis was applied to this study to organise the information flow in the chain for meat production and then to select the best way to implement the traceability system from the farm (livestock production) until the product reaches the finalc ustomer. Three different meat traceability systems were considered, electronic, manual, and hybrid, in a chain scenario of selected actors, while also considering their bi-directional relationships. The main actors in the meat supply chain were identified as suggested by EUCLIDES FILHO (2004), MIRANDA \& MOTTA (2010) and BUAINAIN \& BATALHA (2007). Information flow starts from the livestock producer at the beginning of the chain and flows towards the consumer at the end of the chain (Table 1). The actors were grouped based on their objectives and interfaces to define a unified and embedded protocol (BORGATTI \& LI, 2009). 
TABLE 1. Specifically defined bi-directional relationships among the network actors in the Brazilian meat traceability system.

\begin{tabular}{|c|c|c|}
\hline From & To & Relations hip \\
\hline \multirow{9}{*}{ Farm } & \multirow{3}{*}{ Slaughterhouse } & LIVE DATA \\
\hline & & Delivered Volume (ton) \\
\hline & & Volume (ton) \\
\hline & Local Government & Health Status Certificate \\
\hline & & $\operatorname{Tax}(\$)$ \\
\hline & \multirow{2}{*}{ International Regulations } & Volume (ton) \\
\hline & & LIVE DATA \\
\hline & Private_Compliance & Payment (\$) \\
\hline & Special_Label & Payment (\$) \\
\hline \multirow{2}{*}{ Private_Compliance } & \multirow{2}{*}{ Farm } & Auditing \\
\hline & & Emission of Label Compliance Certificate \\
\hline \multirow{2}{*}{ Special_Label } & \multirow{2}{*}{ Farm } & Auditing \\
\hline & & Emission of Compliance Certificate \\
\hline \multirow{7}{*}{ Slaughterhouse } & \multirow{2}{*}{ Farm } & Requested Volume (ton) \\
\hline & & Payment $(\$)$ \\
\hline & Local Government & $\operatorname{Tax}(\$)$ \\
\hline & \multirow[t]{2}{*}{ International Regulation } & MEAT DATA \\
\hline & & MEAT DATA \\
\hline & \multirow[t]{2}{*}{ Wholesaler } & International Compliance Certificate \\
\hline & & Delivered Volume (ton) \\
\hline \multirow{6}{*}{ Wholesaler } & \multirow{2}{*}{ Slaughterhouse } & Requested Volume (ton) \\
\hline & & Payment $(\$)$ \\
\hline & Local_Government & $\operatorname{Tax}(\$)$ \\
\hline & \multirow{3}{*}{ Retailer } & Requested Volume (ton) \\
\hline & & Payment $(\$)$ \\
\hline & & MEAT DATA \\
\hline \multirow{5}{*}{ Retailer } & Local_Government & $\operatorname{Tax}(\$)$ \\
\hline & \multirow{2}{*}{ Wholesaler } & Requested Volume (ton) \\
\hline & & Payment $(\$)$ \\
\hline & \multirow{2}{*}{ Customer } & Requested Volume (ton) \\
\hline & & MEAT DATA \\
\hline Customer & Retailer & Payment (\$) \\
\hline \multirow{2}{*}{ International_Regulations } & Farm & International Compliance Certificate \\
\hline & Slaughterhouse & Emiss ion of the International Compliance Certificate \\
\hline \multirow{6}{*}{ Local_Government } & \multirow{2}{*}{ Farm } & Infrastructure \\
\hline & & Health Certificate \\
\hline & Slaughterhouse & Health Certificate \\
\hline & Sraugnternouse & Infrastructure \\
\hline & Wholesaler & Infrastructure \\
\hline & Retailer & Infrastructure \\
\hline
\end{tabular}

Data were separated into two different sets: (a) LIVE DATA, which was related to livestock while being reared on the farm and during transportation to the slaughterhouse, and (b) MEAT DATA, which was related to the slaughtered animal and furthermore called meat. A communication protocol was built with the aim of allowing data to flow effectively among the chain elements/actors, as required by international trade standards (Table 2).

Weights were given to the relationships, and the analysis was processed using the UCINET $^{\circledR}$ 6.287 for Windows ${ }^{\circledR}$ (BORGATTI et al., 2002). The graph theory used is a descriptive method based on the vision of the network as a set of nodes connected by links (ABEBE et al., 2010). In this research, the structural measurements of centrality, the identification of network subgroups, and 
the analysis of roles were done using the theory of graphs in the UCINET ${ }^{\circledR}$ software integrated module NETDRAW ${ }^{\circledR}$, which also enabled visualisation of the social network graph data.

TABLE 2. Description of data protocols established when using LIVE DATA and MEAT DATA

\begin{tabular}{ll}
\hline \multicolumn{1}{c}{ LIVE DATA } & \multicolumn{1}{c}{ MEAT DATA } \\
\hline Identity (ID) & ID Code \\
\hline Health Status & Type of cut (description) \\
\hline Environmental/Ethical & Type of processing (description) \\
\hline Labour/Ethical & Processing date (Check Point) \\
\hline Local Government Certificate & Time of storage under refrigeration (including transportation) \\
\hline International Compliance Certificate & Local Government Certificate \\
\hline Special Label Compliance Certificate & International Compliance Certificate. \\
\hline
\end{tabular}

\section{Selection of the most feasible meat traceability system}

The ideal and most complete network structural properties were found by processing data using the initial raw weight of the relationships between all actors. In the next step, the weights were adjusted using correction factors that were obtained from the AHP analysis using the electronic, hybrid and manual systems developed for the on-farm livestock traceability.

Validation was done by tracing ID data from pigs and beef cattle from commercial farms to the respective slaughter houses.

\section{RESULTS AND DISCUSSION}

Although the food network is very complex and it contains a large number of players and characteristics that may be taken into consideration, this specific analysis adopted a more simplified approach which took into account the flow of information, the payments and the product in the food chain.

\section{Selection of a livestock traceability system}

The summary of the overall results (Table 4) indicate that the best alternative for on-farm livestock traceability is the electronic system $(0.430)$, which presented the best score for system reliability (0.158), cost (0.111) and practicality (0.054). The second best alternative was the hybrid system, using a manual system for some specific events $(0.361)$, which presented the best score in safety $(0.112)$. The last alternative in the rank was the manual traceability system $(0.209)$.

TABLE 3. Summary results for the AHP analysis for selecting the most appropriate livestock traceability system with their respective scores.

\begin{tabular}{ccccccc}
\hline $\begin{array}{c}\text { Alte rnative of } \\
\text { Identification } \\
\text { system }\end{array}$ & Reliability & Safety & Cost & Performance & Practicality & Total \\
\hline Electronic & $0.158(1)$ & $0.072(3)$ & $0.111(1)$ & $0.035(2)$ & $0.054(1)$ & $0.430(1)$ \\
Hybrid & $0.146(2)$ & $0.112(1)$ & $0.051(2)$ & $0.017(3)$ & $0.035(2)$ & $0.361(2)$ \\
Manual & $0.037(3)$ & $0.098(2)$ & $0.024(3)$ & $0.038(1)$ & $0.012(3)$ & $0.209(3)$ \\
\hline
\end{tabular}

- Number in parentheses indicates the score

Processes to automatically recognise the identity of an animal are a reliable technology, and because of these technologies, electronic identification systems show great performance potential. Electronic identification and data flow present advantages, including the elimination of labour costs and the error introduced by human manipulation of data (NÄ̈S et al., 2005). The various partners operating in the meat chain are required to apply communication based on product traceability to meet safety and other specificities that are the basis for trade international standards (VILLALOBOS et al., 2010). To implement a good traceability system, a certain degree of data 
recording is needed to generate a minimum basis for keeping the consumer informed. The results from this research agree with other authors (GOSÁLVEZ et al., 2007, SCHEMBRI et al., 2007) who found that, when using electronic traceability systems, the possibility of input errors when transferring data was smaller than when other systems are used.

In international meat trade, most countries have already established a certain scope of control and accreditation and the rules of traceability system are proposed (after the Agreement on Sanitary and Phytosanitary Measures (SPS) of the World Trade Organization (WTO) which is guided by the OIE and Codex Alimentarius), but reliability of information is normally required as consumer awareness increases (ROTH \& DOLUSCHITZ, 2006), and the decrease in using labour intensive systems and the increase in the use of electronic equipment for acquiring information may lead to a reduction in both lack of information and misinformation (MUS, 2006). Initiatives for making information available to producers include preparing manuals, handbooks or protocols and giving specific guidelines for the development of facilities. The implementation of these processes is needed to apply the actions with government/certification organisations and producers (LAMBOOIJ et al., 1999).

\section{Meat traceability network a rray from "farm to fork"}

The Brazilian meat chain includes five sub-systems (BUAINAIN \& BATALHA, 2007): 1) Support system, 2) On-farm production, 3) Processing and Industrialisation, 4) Marketing and 5) Consumer. The meat network graph was derived by inputting the identified relationships (Table 1 and 2) into the NETDRAW ${ }^{\circledR}$ software (Figure 2). The actors' properties were adjusted and organised according to their geodesic framework (ARRANZ \& ARROYABE, 2007). The thickness of the line connecting the nodes/actors is related to their interactions: the thicker the line is, the more interactions there are between those individuals. The obtained values were applied to find the initial parameters to describe the ideal and most complete network (NET 1 Complete, Table 4).

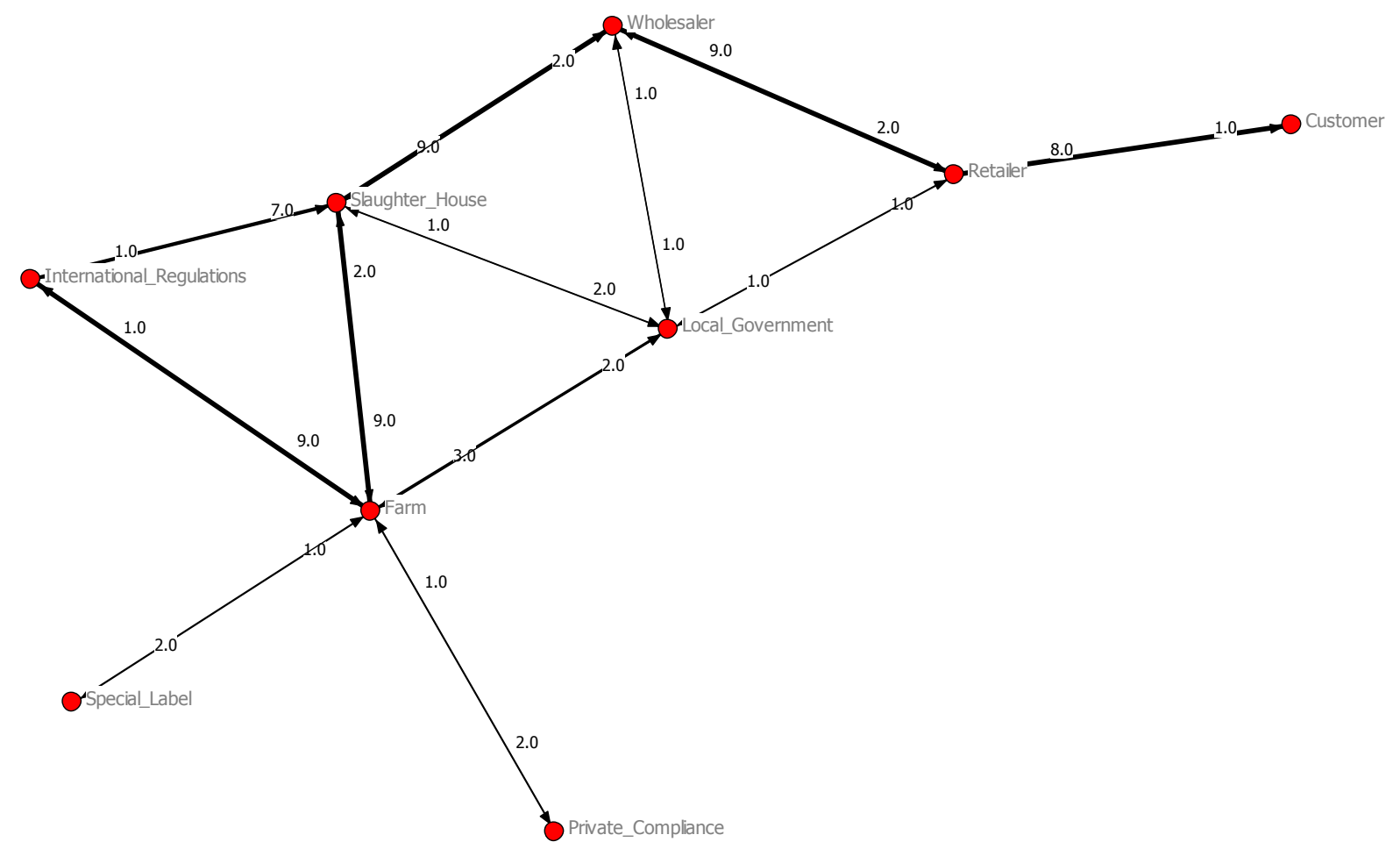

FIGURE 2. Network obtained using the software UCINET $^{\circledR}$ and the module NETDRAW ${ }^{\circledR}$. 
TABLE 4. Comparison of the structural properties of networks using three traceability systems.

\begin{tabular}{ccccc}
\hline NETWORK Parameters & $\begin{array}{c}\text { NET 1 } \\
\text { Complete }\end{array}$ & $\begin{array}{c}\text { NET 2 } \\
\text { Electronic } \\
\text { Factor (AHP) }=\mathbf{0 . 4 4 5}\end{array}$ & $\begin{array}{c}\text { NET 3 } \\
\text { Hybrid } \\
\text { Factor (AHP) =0.361 }\end{array}$ & $\begin{array}{c}\text { NET 4 } \\
\text { Manual } \\
\text { Factor (AHP) = 0.194 }\end{array}$ \\
\hline Density & 0.867 & 0.386 & 0.313 & 0.168 \\
Clustering Coefficient & 0.876 & 0.481 & 0.424 & 0.352 \\
\hline
\end{tabular}

Values that explain the network interactions were obtained for density, degree centrality, closeness centrality, betweenness centrality, clustering coefficient, cliques, $\mathrm{N}$-cliques and geodesic distance. To find out how the network behaved using the three distinct types of livestock traceability, data were processed using the weight values found by the AHP analysis. It was assumed that the criteria used for producing the livestock traceability selection was adequate to be replicated and embedded in the protocol application "from farm to fork". The results show (Table 4) that the network density structural properties, number of current links between the network actors, and the possible links between them in the network change for each livestock traceability system adopted. The only different results were for the properties density and clustering coefficient. When comparing the results of density for each network (NET 2, NET 3 and NET 4) to network 1 (NET 1) the best result was 0.386 , which was related to the electronic data flow system. The second best result was found when using the hybrid system, while the worst result was obtained for the manual system of data flow.

Regarding the clustering coefficient, which is used to evaluate the proximity between the actors of the network, the results show that when using the electronic system (0.481) for data flow, the network structure allows for a better interaction between the actors. The result when using the hybrid system (0.424) was lower than for the electronic system, but it indicates that it could be used in the traceability system with small losses in the quality of data flow. The manual system $(0.352)$ presented a small clustering coefficient indicator when compared to the other two systems, indicating a higher loss of quality in data flow if this system is used, which is not recommended. The remaining network properties did not present change due to the relatively small number of actors and connections considered, and the weights adopted were practically the same within the three scenarios. In previous studies SAMADDAR \& KADIYALA (2006) present in difficulty in identifying the network properties in the area of supply chain collaboration using a limited number of actors, which is also pointed out by BORGATTI \& LI, (2009).

The design of a good traceability system needs to provide reliability to the consumer, which is accomplished by reliable data inputs and proper data flow (FERRIER \& LAMB, 2006). With a suitable traceability system, a purchaser might be able to verify production conditions and inspection protocols in addition to the information that is already provided, such as the packing date, place, and producer, and all of that information could be recovered through product labelling to identify specific product features (HOBBS, 2004). When the density is higher, the strength of the network ties are greater, meaning that more information is exchanged by the actors, which usually means better data flow.

The clustering coefficient ([eq. (3)]) was defined as:

$$
\mathrm{C}_{i}=2 n / k_{i}\left(k_{i}-1\right)
$$

where,

$n$ represents the number of direct links connecting the $k_{i}$ nearest actors of node $i$; it is equal to 1 for a node at the centre of a fully interlinked cluster, and it is equal to 0 for an actor that is part of a loosely connected group. Therefore, $\mathrm{C}_{i}$, the average over all nodes $i$ of a network, is a measure of the network's potential modularity. The results from the SNA suggest that both electronic and hybrid traceability systems can supply nearly 50\% potential modularity between active actors, providing acceptable tracking/tracing of the data flow (VILLALOBOS et al., 2010; HOBBS, 2004). 
An effective traceability program limits contamination problems and reduces the cost to companies due to a recall or market withdrawal (PETERSEN et al., 2002; MUS, 2006). Accurate and more complete tracking records for meat products can reduce the impact of a product recall by limiting the scope because potentially affected products can be better defined and contained (HOBBS, 2004). According to SCHNETTLER et al. (2009) the information currently present on meat labels is useful for consumers, who would also value having information on other attributes associated with on-farm livestock production, such as the production system, feeding and animal welfare.

During 2013, Brazil produced nearly 12 million tons of beef and pork meat, and 3 million tons were exported, mainly to the European Union and Asia (ABIEC, 2013). Brazilian meat production represents $40 \%$ of the country's agricultural GNP, and exports have been increas ing since the 1990s outbreak of bovine spongiform encephalopathy (BSE, or "mad cow" disease) in Europe (MIRANDA \& MOTTA, 2010). Although it is becoming an important player in the international meat market, the Brazilian meat industry needs to update its traceability level, especially in technical aspects, to be prepared for the increase in global competition. The use of adequate tracing/tracking technology in the supply chain may lead to data that can warranty certain product qualities, enabling producers and other actors in the chain to respond for the chain safety "from farm to fork".

\section{CONCLUSIONS}

It was found that the most suitable meat traceability system "from farm to fork" that can be used by Brazilian producers for international trade is the electronic-supported system. Results also indicate that the chain nodes where data flow were implemented using the hybrid system may also be acceptable; however, the manual system is not recommended in international trade because the structural properties of density and cluster coefficient were low.

\section{ACKNOWLEDGEMENT}

The authors would like to thank the National Council for Scientific and Technological Development - CNPQ for financial support.

\section{REFERENCES}

ABEBE, M.; ANGRIAWAN, A.; TRAN, H. Chief executive external netw ork ties and environmental scanning activities: an empirical examination. Strategic Management Review, Ottawa, v. 4, n. 1, p. 3043, 2010.

ABIEC. BRAZILIAN ASSOCIATION OF EXPORT MEAT INDUSTRIES, Statistics. 2013. Available at: 〈http:// http://www.abiec.com.br/texto.asp?id=31〉. Accessed on: 6 may 2014.

ARRANZ, N.; ARROYABE, J.C.F. Governance structures in R\&D networks: An analys is in the European context. Technological Forecasting and Social Change, Amsterdam, v. 74, n.5, p. 645-662, 2007.

BORGATTI, S.P.; EVERETT, M.G.; FREEMAN, L.C. UCINET for WINDOWs: software for social network analys is. Lexington: Analytic Technologies, 2002. 275p.

BORGATTI, S.P.; LI, X. On social netw ork a nalys is in a supply chain context. Journal of Supply Chain Management, Tempe, v. 45, n. 2, p. 5-22, 2009.

BUAINAIN, A.M.; BATALHA, M.O. Cadeia produtiva da carne bovina. Brasília: Instituto Interamericano de Cooperação para a Agricultura: Brasília. 2007. Disponível em: <http:// http://www.iica.org. br/Docs/CadeiasProdutivas/Cadeia\%20Prod utiva\%20da\% 20Carne\%20B ovina\%20c \%20capa.pdf>. Acesso em: May 10, 2012.

EUCLIDES FILHO, K. Supply chain approach to sustainable beef production from a Brazilian perspective. Livestock Production Science, Amsterdam, v. 90, n. 1, p. 53-61, 2004. 
EXPERT CHOICE. Expert Choice 11.5. 2009. Available at: 〈http//www.expertchoice.com/>. Accessed on: 12 aug. 2010.

FERRIER P, LAMB R. Government regulation and quality in the US beef market. Food Policy, Oxford, Elsevier, v.32; n.2, p. 84-97, 2006.

GOSÁLVEZ, L.F.; SANTAMARINA, C.; AVERÓS, X.; HERNÁNDEZ-JOVER, M.; CAJA, G,; BABOT, D. Traceability of extensively produced Iberian pigs using visual and electronic identification devices from farm to slaughter. Journal of Animal Science, Champaign, v. 85, n. 10, p. 2746-2752, 2007.

HOBBS, J.E. Information asymmetry and the role of traceability systems. Agribusiness, New York, v.20, n. 4, p. 397-415, 2004.

LAMBOOIJ, E.; VAN'T KLOOSTER, C.E.; ROSSING, W.; SMITS, A.C.; PIETERSEN, C. Electronic identification with passive transponders in veal calves. Computers and Electronics in Agriculture, New York, v. 24, n. 1, p. $81-90,1999$.

MIRANDA, S. H. G.; MOTTA, M. A. S. B. Exportação de carne bovina brasile ira: e volução por tipo e destino. In: BRAZILIAN CONGRESS OF ECONOMICS AND RURAL SOCIOLOGY, 32., 2010. Recife. Proceedings... Recife: SOBER, 2010. p. 1-13.

MUS, M. Traceability system approaches and cost analysis for the beef industry. Washington. 2006. 101f. Master' (Dissertation Master of Arts in Economics) - Washington School of Economics Sciences, Washington, 2006. A vailable on:

<http://www.dissertations.wsu.edu/Thes is/Summer2006/m_mus_072006.pdf>. Accessed on: May 10, 2012

NÄÄS, I.A.; CAMPOS, S.; SILVA, K.O. Comparison of Manual and electronic traceability in swine production. Agricultural Engineering International: The CIGR Ejournal, Colle ge Station, v.7, v. 1-8, 2005.

PETERSEN, B.; KNURA-DESZCZKA, S. E.; PÖNSGEN-SCHMIDT, E.; GYMNICH, S. Computerised food safety monitoring in animal production. Livestock Production Science, New York, v. 76, n. 3, p. 207-213, 2002.

RICHARDSON, A.J. Regulatory networks for accounting and auditing standards: A social network analysis of Canadian and international standard-setting. Accounting, Organizations and Society, London, v. 34, n. 5, p. 571-588, 2009.

ROTH, M.; DOLUSCHITZ, R. Cost-benefit-analysis of quality-and traceability systems supply-chains of animal products. 2006. A vailable at:

<http://www.itfoodtrace.org/date ien/EFITA_Roth_Doluschitz.pdf〉. Accessed on: 10 dec. 2009.

SAATY, T.L. The analytic hierarchy process. New York: Mc Graw-Hill, 1980. 264p.

SAMADDAR, S.; KADIYALA, S.S. An analys is of inter-organizational resource sharing decisions in collaborative know le dge creation. European Journal of Operational Research, Amsterdam, v. 170, n. 1, p. 192-210, 2006.

SCHEMBRI, N.; SITHOLE, J.A.; HERNÁNDEZ-JOVER, T.M.; HOLYOAKE, P.K. Lifetime traceability of weaned pigs in concrete-based and deep-litter production systems in Australia. Journal of Animal Science, Champaign, v. 85, n. 11, p. 3123-3130, 2007.

SCHNETTLER, B.M.; SILVA, R.; SEPÚLVEDA, N.B. Utility to consumers and consumer acceptance of information on beef labels in Southern Chile. Chilean Journal of Agricultural Research, Santiago, v. 69, n. 3, p. 373-382, 2009.

VAIDYA, O. S.; KUMAR, S. Analytic hierarchy process: An overview of applications. European Journal of Operational Research, Amsterdam, v.69, n. 1, p. 1-29, 2006.

VILLALOBOS, P.; PADILLA, C; PONCE C.; ROJAS, A. Beef consumer preferences in Chile: importance of quality attribute differentiators on the purchase decision. Chilean Journal Of Agricultural Research, Santiago, v. 70, n. 1, p.85-94, 2010. 